\title{
Local perspectives on transnational relations of Cameroonian migrants
}

\author{
Michaela Pelican \\ Department of Social Anthropology \\ University of Zurich, Switzerland \\ Peter Tatah \\ Department of Anthropology \\ University of Yaoundé 1, Cameroon \\ Basile Ndjio \\ Department of Anthropology \\ University of Douala, Cameroon
}

\section{Introduction}

International migration is a crucial theme widely discussed in Cameroon, both privately and in public. While individuals have long been travelling, studying and living abroad, the vision of finding a better future elsewhere has gained prominence over the past fifteen years. It has become a popular conviction that Cameroon has little to offer to its economically, intellectually and - arguably - politically aspiring citizens.

This development has to be seen in the context of the country's economic and political liberalisation of the 1990s. In line with structural adjustment programmes, government employment has decreased significantly, and with the devaluation of the FCFA in 1994, local buying power has drastically reduced (Konings 1996, Monga 1995). Moreover, the country's democratisation has been accompanied by an increase in corrupt and illegal practices (Eboussi Boulaga \& Zinga 2002). As the civil unrest of February 2008 confirms, ${ }^{1}$ many Cameroonians are dissatisfied with the country's 'cosmetic democracy' (Nyamnjoh 2002, see also Ngwane 2004). Thus, in the absence of valid prospects of a decent future at home, many Cameroonians have turned to alternatives elsewhere. Most have focused on the West, i.e. the US and Europe, where economic and educational opportunities are thought to be plentiful. However, with increasing restrictions on migration to Western countries, alternative destinations within Africa and in the Near and Far East have gained currency.

The issue of Cameroonians' urge for international migration and the possible impact of Cameroonian migrants on their home communities was the subject of a collaborative research project involving three anthropologists and ten graduate students of the University of Zurich (Switzerland) and the University of Yaounde 1 (Cameroon). ${ }^{2}$ The project was conducted in Cameroon in July to September 2007 and entailed a one-week preparatory seminar, four weeks of field research and one week of data analysis. The project was generously supported by the Swiss National Science Foundation and the Laboratoire CASS-RT in Yaoundé.

\section{Research design}

The focus of the project was on transnational relations of Cameroonian migrants within the non-Western world, and the perception of these relations by members of the 
migrants' communities of origin. Transnationalism here refers to mobility across multiple national borders and to migrants entertaining regular and sustained contacts with individuals and communities in two or more nation states.

Starting with the above hypothesis that - besides migration to the West-alternative destinations have gained currency, we centred our investigations on three regional clusters: While a first team focused on intra-African migration, a second engaged with the migration of Muslim Cameroonians to Arab countries, and a third researched Chinese-African exchange relations. All three teams collected data on the motives of migration, preferred destinations, networks of migration, the role of the family in the migration enterprise, communication and exchange relations between migrants and their relatives and friends at home, as well as the perception of migrants in their host and home countries. The research team on migration to Arab countries further investigated the role of religion for Muslim migrants, while the China-Africa team collected additional information on the Chinese presence in Cameroon. In order to diversify our findings, we conducted research in three locations, i.e. in the two major cities Yaoundé and Douala in francophone Cameroon, and in Bamenda and its rural surroundings in the Anglophone part of the country.

In terms of methodology we worked with informal and structured interviews as well as e-mail communication with migrants living abroad. In total, we talked to approximately eighty informants, including migrants' relatives and friends, prospective migrants and return migrants. In researching exchange relations we also used photographic documentation. Due to the brief research period, all project participants were encouraged to capitalise on existing contacts with migrants or their family members. Unfortunately, our attempts at collecting quantitative data from foreign embassies and the Cameroonian immigration service yielded no valid information.

\section{Theoretical framework}

Transnationalism is a relatively new approach to the study of migration which was introduced in the mid-1990s by a group of female anthropologists working on migration from Asia and Central or Southern America to the United States (Glick Schiller et al., 1995, Glick Schiller 2004). Up to then, classical theories of migration have worked with the concepts of assimilation, ethnic pluralism and multiculturalism, thus focusing on various trajectories and frameworks of migrants' economic, legal and cultural integration into the receiving nation state (for example, Handlin 1951). As classical migration research was informed by the political question of how to ensure migrants' loyalty to their chosen country of residence, most authors ignored the possibility of migrants simultaneously entertaining social, economic or political relations with both their host and home countries. This latter perspective has been adopted by the proponents of transnationalism who study migrants' contacts and activities across national borders as well as the practicalities of multiple loyalties. Some are also concerned with the question of the degree to which transnational social spaces offer alternative economic, political and social avenues from which not only migrants but also sending and receiving states could benefit. A number of authors have argued that it is no coincidence that the new paradigm of transnational migration emerged in the 1990s, but reflects transformations in migration patterns, linked to new 
communication technologies, increased mobility and other aspects of globalisation (Portes et al., 1999, Vertovec 1999).

While the majority of classical and contemporary studies have engaged with migration from the South to the North (i.e. the US and Europe), alternative developments have also been documented. For example, over the past twenty years, migration within Africa has increased significantly due to acute political and economic crises, resulting in waves of refugees, irregular migration and increased labour migration (Adepoju 2004, Whitwell 2002). Taking into account these recent trends in migration and research, we considered it useful to focus on South-South migration and to contribute to the theoretical framework of transnational migration by adding an African perspective to the dominantly Euro-American approach. In the following we will summarise our major findings and relate them to existing research.

\section{'Bush faller': Cameroonians' longing for international migration}

The focus of Cameroonians on international migration as the only way to a better future has been reflected in many conversations with informants: 'Everyone wants to leave - if not legally, then illegally'. 'Those who are still here, are the ones who haven't made it yet.'

Paradigmatic for the idea of a better life elsewhere is the concept of the bush faller (in Pidgin English, the lingua franca in Anglophone Cameroon). A bush faller is 'someone who made it', i.e. who left Cameroon and now leads a good life in the West. As the etymology of the term shows, falling bush implies going to the bush to hunt, gather or harvest; i.e. one never returns from the bush with empty hands. But the bush has a double connotation: on the one hand it is associated with wilderness and backwardness, on the other with places of enrichment - thus the US and Europe equally qualify as bush.

While bush faller is a novel term, there have been earlier concepts, such as been to which refers to elite members of the post-colonial era who, with the help of mission networks or personal connections, studied abroad, and returned to Cameroon to take up white-collar jobs with the government or international corporations. In comparing the two notions, a shift in ideals of personal success is evident: Whereas been to implies mainly educational achievement and is a term no longer in use, bush faller is associated with adventure and self-enrichment. ${ }^{3}$

As most Western countries have fortified their borders with the aim of reducing the number of immigrants, migration to the US and Europe has become more difficult. Many Cameroonians, however, have not given up but have tried alternative, often illegal ways, some successfully, others with negative experiences. ${ }^{4}$ For a long time, migrants have emphasised economic and educational success in recounting their experiences at home; thus international migration until recently has been considered in a positive light. Over the past years, however, new perspectives have emerged with much more critical and ambivalent undertones. For example, in August 2007 the Cameroonian feature film 'Paris à tout prix' (by Josephine Ndongo) opened nationwide. It tells the suffering of a young woman who ended up in Europe as a prostitute. Furthermore, a book entitled From dust to snow (edited by Lydia and Wilfred Ngwa) was released and sold in Cameroonian bookstores, in which migrants (predominantly Cameroonian students) told of their positive and negative experiences 
of living and studying in the West. To which degree and in which ways these novel, critical perspectives have a lasting impact on local perceptions of international migration remains to be seen.

While for many Cameroonian migrants the US and Europe remain their 'dreamdestinations', their movements are not limited to the West. Neighbouring countries such as Gabon and Nigeria have long been established migration destinations, and over the past years, other African countries, such as South Africa, as well as destinations in the Near and Far East (Dubai and China) have gained currency.

\section{Intra-African migration}

Migration has been a relevant feature since the pre-colonial period in Africa in general and Cameroon in particular (Warnier 1985). Most studies, however, have focused on seasonal/labour/urban migration without paying much attention to national borders (Gluckman 1941, Konings 2001, van Velsen 1971). In line with the recent shift in migration studies, new research projects have emerged that investigate transnational migration within Africa and return migration from Europe to Africa (Hahn \& Klute 2007, Martin 2005). ${ }^{5}$ As some researchers have argued, southern Africa (in particular Botswana and South Africa) have become an attractive destination for labour migrants. As a result, discourses on xenophobia have increased in these countries (Crush \& McDonald 2000, Lubkemann 2000, Nyamnjoh 2006).

In Cameroon as well, South Africa has become one of the preferred destinations within Africa. Other targets are Gabon, Ghana, Nigeria, Equatorial Guinea and the Democratic Republic of Congo. Many migrants fit their choice of destination to their financial resources. Those who have enough money and connections to travel to the US or Europe would not choose an African country. South Africa features as a possible alternative, as it may offer opportunities to continue to the West. Cameroonians here are valued as skilled hairdressers and as outstanding in the intellectual domain. The neighbouring country Gabon features as an option for those with limited capital, and also runs an employment programme for English teachers. At the same time, Gabon has the reputation of a country in which Cameroonians are treated as foreigners with very limited rights. Thus African destinations are scaled: South Africa counts as the United States of Africa, and migrants living there are considered 'bush fallers'. Other African countries, however, are less valued.

Among the reasons for migration are unemployment, poverty, the search for educational opportunities, business, adventure, religious travel and family reunion. Although many migrants may be motivated mainly by economic incentives, we have to assume a mix of different and changing reasons. The majority of migrants are young men and women, mostly from the middle or lower strata of Cameroonian society. As Fleischer (2006) has argued with regard to Cameroonians living in Germany, the family plays a significant role in the decision making and in the preparation of the journey. Similar to her findings, most of our informants confirmed that families generally support the migrants' endeavour both morally and financially. However, the preparatory phase is generally characterised by extreme secrecy and caution. In the early stage only the closest kin are informed, as migrants fear the possible interference of envious or mischievous relatives. Such interferences may be of practical or occult character, and may lead to the failure of the migration enterprise. Consequently 
migrants publicise their journey only when all preparations are completed, and the visa stamp is in the passport. Another reason for their secrecy is their apprehension that close relatives may disagree with their planned adventure. For many, a break with their family is unacceptable, and the blessings of their parents are absolutely necessary, as no one can be sure of his or her future success.

Most migrants have regular contact with their relatives and friends at home. Frequently, however, they need time to establish themselves, before they initiate contact. Mobile phones are the most common way of communication, while letters and e-mails are used to a lesser degree. Mobile phone networks have been operative in Cameroon since the late 1990s, and the latest mobile phone models are among the most wanted presents. A large number of migrants regularly send money or goods to Cameroon. Those who live in distant places normally take the opportunity of money transfer via for example Western Union. The distribution of the money is entrusted to a close relative or friend at home (often stationed in Douala or Yaoundé) with detailed instructions of the amount of money to be paid to each person or the goods to be bought. Conversely, migrants living in nearby countries request fellow Cameroonians travelling home to take money or goods along. Frequently, however, these items do not arrive at their intended destination. Thus many migrants prefer to save their presents, until they themselves travel home.

A number of informants remarked that incessant or exaggerated requests for goods and remittances by members of the extended family are a nuisance and burden to migrants. Consequently, some limit their communication to a minimum. Similarly, Nyamnjoh (2005) reported that Cameroonians living in 'Whiteman Kontri' (the West) compare themselves to zombies - threatened by their relatives with witchcraft attacks and enslaved to work for the latters' enrichment without consideration for their personal wellbeing. It is important to remark, however, that exchange relations between migrants and their families are not one-sided. Frequently, relatives also support the migrants with goods, such as spices or food items, to give them a flavour of home. Moreover, they provide spiritual services, such as blessings, prayers, rituals, thanksgiving and almsgiving (sarika), to ensure their success and spiritual fortification. This spiritual support is considered crucial and is highly valued by most migrants.

\section{Migration of Cameroonian Muslims to Arab countries}

The migration desires and experiences of Muslim West Africans is a neglected subject that merits further research. One body of literature related to this field is concerned with historical slavery and forced migration mostly from Eastern Africa to the Mediterranean and Arab world (Alpers 1997, Hunwick \& Powell 2001, Lewis 1976). Another group of studies deals with contemporary transnational relations of Muslim migrants from West Africa, concentrating mainly on brotherhoods from Senegal and Mali and their connections to Europe and the US (Babou 2002, O. Kane 1997, Riccio 2001, Soares 2004). Among other things, these studies indicate that the Islamic networks create a transnational public space which migrants employ for economic activities. Furthermore, they offer them social and moral support, and confirm their construction of a distinct West African Muslim identity. 
In Cameroon there is no comparably strong and well organised brotherhood as, for example, the Murid order of Senegal. Nonetheless, Muslim Cameroonians participate in international migration, and among their favoured destinations are Saudi Arabia and the Arab Emirates (Dubai). The Gulf States constitute a region with a high demand for foreign labour (Whitwell 2002); and while most labour migrants there are from South Asia or the Middle East, there may also be opportunities for West Africans.

Our research team on Muslim migration to the Arab world concentrated its inquiries on the Briquetterie, considered the main Muslim quarter of Yaoundé. For many of its inhabitants, Arab countries are preferred destinations of migration. Primary motives for migrating to Saudi Arabia, Egypt, Libya or the Sudan include education, trade and prospective marriage partners. For example, the Saudi embassy offers stipends for Islamic Studies to African Muslims. While men may study in Saudi Arabia or other Muslim countries, women are offered stipends only for the International University of Africa in Khartoum.

In Yaoundé there are a number of national and international Islamic networks which may assist the aspiring migrants in the preparations for their journey. One well established means of travelling is the pilgrimage to Mecca which, besides religious accomplishment, may offer also economic incentives. Many pilgrims take along trade goods which they sell during their journey and then return with souvenirs from Mecca (for example, clothes, decorative items), widely desired among the Muslim community in Yaoundé. The pilgrimage is one of the few travel options also available to single women. As mentioned by some informants, the latter may even aspire to find an appropriate husband during their journey. However, to which degree single African women may remain in Saudi Arabia and establish contacts with Arab men remains an open question which requires further research in Saudi Arabia. ${ }^{6}$

In addition to Islamic networks, family relations play a significant role in the planning and execution of the journey. Unlike the case of intra-African migration, Muslim migrants are less apprehensive and secretive in the planning of their travels, as the possibility of studying in Saudi Arabia or Sudan is seen as a blessing for the whole community. Frequently, the stipends offered to the migrants are too little to cover even their living expenses and, in the absence of work opportunities, they remain dependent on the financial support of their families. Thus many students have regular contact with their relatives and friends - mainly through letters, since mobile phones are not easily accessible or relatively expensive. Here as well, the support is mutual and pilgrims often act as carriers of presents in both directions.

For Muslim students their stay abroad is limited in time; after finishing their studies, they are required to return home. Back in Cameroon there are only very few jobs where they can apply their acquired training. Some are lucky to be employed with Islamic organisations; others work voluntarily or for a small salary as Koranic teachers.

\section{Chinese-Cameroonian exchange relations}

A substantial Chinese presence in Africa is a relatively recent but significant phenomenon. While academic interest in Chinese-African relations has started only recently, the body of literature is growing at a constant rate. ${ }^{7}$ 
China has shown an increasing interest in opening up new markets and investment opportunities and in accessing the energy resources of the African continent. In return, it has offered debt forgiveness and development assistance as well as strategic partnerships with African governments (Alden 2005, van den Looy 2006). The latter are equally interested in collaborating with China as they envision new business opportunities and ways to bolster regime stability. As Alden (2005) argues, several African countries have benefited from Chinese investment and tourism. Moreover, China's policy of 'cooperation free of political conditionality' has opened new avenues for those governments notorious for human-rights violations or engagement in armed conflict. Yet members of the public may perceive the presence of Chinese workers and entrepreneurs less positively than African governments. As Dobler (2007) has noted with regard to Oshikango in northern Namibia, locals have responded to the rapid expansion of Chinese enterprises with discourses of xenophobia.

An increased Chinese presence can also be noted in Cameroon, mainly in the country's major cities Yaoundé and Douala. Many Chinese are entrepreneurs running shops with Chinese import goods or Chinese restaurants. Some of the latter are exclusively for Chinese customers and also offer opportunities to Chinese sex workers (Ndjio 2007). Others engage in the agricultural sector, growing vegetables, raising chickens or fishing; their products are destined primarily for Chinese customers in Cameroon. A third group are workers in Chinese construction companies, employed to build roads and public buildings, such as the new football stadium in Yaoundé.

Compared to the business opportunities Chinese encounter in Africa, their country offers little migration incentives to Cameroonians. Nonetheless there are a few who have moved to China and work as translators or coordinate trade with African customers. Over the past years there has been a demand for English teachers, which motivated some Anglophone Cameroonians to move to China. This option, however, has turned out to be ambiguous. Many of the teachers are sent to rural areas where they have to work long hours for little money. In addition, they face considerable communication problems, as only few made an attempt to learn Chinese before leaving Cameroon. Some informants also complained about latent racism. In China an American accent is in demand and so they saw it necessary to pretend to be AfroAmericans. But although China is considered 'no bed of roses', it is seen as offering the possibility of moving on to the US.

Local perspectives on Chinese-Cameroonian relations are ambivalent. Many parents support the decision of migrants, hoping for their economic success in China. On the other hand, the strong presence of Chinese and their goods in Cameroon has produced frequent criticism, particularly by Cameroonian businesspeople who see their interests endangered. Cameroonian consumers, as well, have expressed their dissatisfaction; on the one hand, the Chinese offer a wide range of goods at all prices, so 'there is something for every purse'. On the other, the quality of the cheap items is often so poor that Cameroonians complain about being dumped with substandard goods. Finally, the attempt of Chinese individuals to enter the informal sector has raised criticism and incomprehension among Cameroonians. Many are wondering, why these 'whites' (Chinese as well as Europeans and Americans are considered 'whites' on the basis of their skin complexion) debase themselves to such a degree that they even sell homemade cakes in the streets. Seemingly, China must be even poorer than 
Cameroon. This consideration contributed to China's decreasing attraction for Cameroonian migrants, as compared to other destinations in Africa, the Near East and the West.

\section{Conclusion}

These elaborations represent the preliminary results of a brief research project centring on 'local perspectives on transnational relations of Cameroonian migrants', conducted by Swiss and Cameroonian anthropologists and graduate students. The aim of the project was to gain a basic overview over Cameroonians' ideas and experiences of international migration, particularly with regard to South-South migration, and to identify subject areas that merit further research.

One such area concerns the relevance of spiritual or occult aspects of migration. As outlined above, the preparatory phase of migration is characterised by secrecy and caution due to migrants' apprehension of practical or occult interferences. Yet the threat of occult aggression also remains valid during the migrants' stay abroad. Relatives play a significant role in this regard, both as possible sources of occult aggression and in providing spiritual protection. In-depth research into the ambivalent role of the family and practices of secrecy surrounding the migration enterprise may prove informative. As concerns the study of exchange relations between migrants and their families, there has been a one-sided focus on remittances and goods sent by migrants, while the economic, moral and spiritual support provided by relatives and friends has largely been neglected. We suggest that both directions of exchange relations ought to be considered.

Researchers of transnationalism also concern themselves with national frameworks of migration. In this respect, we believe detailed research into the migration of Muslim Africans to Arab countries will yield valuable information. In particular, researchers may investigate the motives of Muslim governments for supporting African students, as well as the impact of the migrants' experience and Islamic training on ideals and realities at home.

Finally, as concerns research on Chinese-African relations, this is a vibrant field particularly for anthropologists, as the majority of observations, so far, have been contributed by economic and political scientists. On the basis of our own experiences, we see the potential for a very fruitful collaboration of Chinese and African social scientists, thus integrating both perspectives. A first step in this direction was realised in the conference 'China in Africa: Who benefits?', co-organised by the Interdisciplinary Centre for East Asian Studies in Frankfurt (December 14-15, 2007), which brought together European, African and Chinese academics and policy makers. ${ }^{8}$ We look forward to more such international and interdisciplinary collaborations - not only with regard to research on Chinese-African relations, but more generally in the field of transnational migration.

\section{Notes}

1. For reports on the upheavals responding to rising oil prices and the President's attempts to change the Cameroonian constitution, allowing him to stay in power unlimitedly, see for example. BBC News, 29.02.08. 'Deadly violence rages in Cameroon', (http://news.bbc.co.uk/2/hi/africa/7268861.stm), The Post (Buea), 11.04.2008. Cameroon: Amending the Constitution for One Man (http://allafrica.com/stories/200804110638.html). 
2. The project participants were Dr des Michaela Pelican (University of Zurich), Dr des. Peter Tatah (University of Yaoundé 1), Dr Basile Ndjio (University of Douala), as well as Achu Owen Teneng, Afu Isaiah, Arrey Marie Tudor, Constance Chamu, Datidjo Ismaila, Deli Teri Tize, Delphine Nchufuan Fongo, Emmanuella Nsaise Maimo, Emuke Nnoko Ngaaje and Laurentine Mefire Mouchingam. Academic and technical support was provided by Prof Dr Antoine Socpa (University of Yaoundé 1, Laboratoire CSS-RT) and Francis Njilie (Laboratoire CASS-RT).

3. The term 'been to' and its vernacular equivalent 'woyayie' (the one who 'has arrived') are also used in Ghana (Martin 2005, van Dijk 2002). A similar notion to 'bushfaller', yet with a much longer history, is 'Jaguar', widely used in Western Africa (see Rouch 1954/1976, Stoller 1999).

4. For example, Olivier Jobard has made a photographic documentation of the illegal migration of Kingsley, a young man from Limbe, Cameroon (available at http://www.mediastorm.org/0010_NST.htm.)

5. See also the African Migrations Programme of the International Migration Institute (IMI) in Oxford, UK (http://www.imi.ox.ac.uk/research/african-migrations-programme); the Special Issue on Africa of the online journal Migration Information Source of the Migration Policy Institute in Washington, US (http://www.migrationinformation.org/ issue_sep04.cfm); the Transnational Migration, Return and Development in West Africa (TRANSREDE) research project of the Sussex Centre of Migration Research, UK. (http://www.sussex.ac.uk/Units/SCMR/research/transrede/).

6. In an article on Nigerian sex workers Onyeonoru (2004: 116) mentions that the Saudi Arabian authorities protested against the influx of Nigerian prostitutes into Saudi Arabia.

7. The African Studies Centre (ASC) in Leiden put together a web dossier on China-Africa relations, available on their library homepage (http://www.ascleiden.nl/Library/Webdossiers/ChinaAndAfrica.aspx).

8. Conference presentations are available on: http://www.izo.uni-frankfurt.de/Aktuell.html.

\section{References}

Adepoju, Aderanti, 2004, 'Trends in international migration in and from Africa', in D.S. Massey and J.E. Taylor, eds., 2004, International migration prospects and policies in a global market, Oxford: Oxford University Press.

Alden, Chris, 2005, 'China in Africa', Survival Autumn 2005: 147-164.

Alpers, Edward, 1997, 'The African Diaspora in the Northwestern Indian Ocean: Reconsideration of an old problem, new directions for research', Comparative Studies of South Asia, Africa and the Middle East, 17(2): 62-81.

Babou, Cheikh Anta Mbacké, 2002, 'Brotherhood solidarity, education and migration: The role of the dahira among the Murid community of New York', African Affairs 403: $151-170$.

Crush, Jonathan and David A. McDonald, eds., 2000, 'Transnationalism, African immigration and new migrant spaces in South Africa', Special issue of Canadian Journal of African Studies 43 (1).

Dobler, Gregor, 2007, 'Solidarity, Xenophobia and the Regulation of Chinese businesses in Oshikango, Namibia', in Chris Alden, Daniel Large, Ricardo Soares de Oliveira, eds., China Returns to Africa. London: Hurst.

Eboussi Boulaga, Fabien and Valentin Siméon Zinga, 2002, Fight Against Corruption: is there anything impossible with Cameroonians. Yaoundé: Presses Universitaires d'Afrique.

Fleischer, Annett, 2006, Family, obligations, and migration: the role of kinship in Cameroon, MPIDR Working Paper WP 2006-047. 
Glick Schiller, Nina, Linda Basch and Cristina Blanc Szanton, 1995, 'From immigrant to transmigrant: theorizing transnational migration', Anthropological Quarterly 68 (1): 4863.

Glick Schiller, Nina, 2004, 'Transnationality', in David Nugent and Joan Vincent, eds., $A$ Companion to the Anthropology of Politics. London: Blackwell: 448-467.

Gluckmann, Max, 1941, Economy of the central Barotse plain, Rhodes-Livingstone Paper 7.

Hahn, Hans-Peter and Georg Klute, eds., 2007, Cultures of migration. African perspectives. Berlin: Lit.

Handlin, Oscar, 1951, The Uprooted: The epic story of Great Migration that made the America People, New York, Atlantic Little, Brown Books.

Hunwick, John and Eve Troutt Powell, 2001, The African Diaspora in the Mediterranean Muslim World, Princeton, NY: Markus Wiener Publishers.

Kane, Ousmane, 1997, 'Muslim missionaries and African states', in Susan Hoeber Rudolph and James Piscatori, eds., Transnational religion and fading states Boulder, Colorado: Westview Press. pp. 47-62.

Konings, Piet, 1996, 'The post-colonial state and economic and political reforms in Cameroon', in Alex Fernandez Jilberto and André Mommon, eds., Liberalisation in the Developing World: institutional and economic changes in Latin America, Africa and Asia. London, New York: Routledge.pp. 244-265.

Konings, Piet, 2001, 'Mobility and exclusion: Conflicts between autochthons and llochthons during political liberalization in Cameroon', in M. de Bruijn, R. van Dijk and D. Foeken, eds., Mobile Africa: Changing patterns of movement in Africa and beyond, Leiden: Brill, pp. 169-194.

Lewis, Bernard, 1976, 'The African diaspora and the civilization of Islam', in Martin Kilson and Robert Rotberg, eds., The African Diaspora: interpretative essays. Cambridge: Harvard University Press. pp. 37-56.

Lubkemann, Stephen, 2000, 'The transformation of transnationality among Mozambican migrants in South Africa', Canadian Journal of African Studies 34 (1): 41-63.

Martin, Jeannette, 2005, Been-to, Burger, Transmigratent? Zur Bildungsmigration von Ghanaern und ihrer Rückkehr aus der Bundesrepublik Deutschland. Münster: Lit.

Monga, Célestin, 1995, Trade Reform and Exchange Rate Issues in the CFA Zone. Working papers in African Studies no. 195, African Studies Center, Boston University.

Ndango, Josephine, 2007, Paris à tout prix. Feature film, 90 mins.

Ndjio, Basile, 2007, 'Shanghai beauties and African desires: Migration, Trade and Chinese Prostitution in Cameroon', Paper presented at the international conference 'China in Africa: Who benefits? Interdisciplinary perspectives on China's involvement in Africa', Frankfurt, 14-15.12.2007.

Ngwa, Lydia and Wilfred, eds., 2006, From dust to snow: Bush-faller. Princeton: Horeb Communications.

Ngwane, Mwalimu George, 2004, 'Cameroon's democratic process: vision 2020', CODESRIA Bulletin 3\&4: 20-26.

Nyamnjoh, Francis, 2002, Insiders and outsiders. Citizenship and xenophobia in contemporary Southern Africa, Dakar: CODESRIA/London: Zed.

Onyeonoru, Ifeanyi, 2004, 'Pull factors in the political economy of international commercial sex work in Nigeria', African Sociological Review 8 (2): 115-135.

Portes, Alejandro and Luis Guarnizo and Patricia Landolt, 1999, 'The study of transnationalism: Pitfalls and Promise of an Emergent Research Field', Ethnic and Racial Studies 22 (2): 217 237. 
Riccio, Bruno, 2001, 'From 'ethnic group' to 'transnational community'? Senegalese migrants' ambivalent experiences and multiple trajectories', Journal of Ethnic and Migration Studies 27 (4): 583-599.

Rouch, Jean, 1954/1976, Jaguar. Documentary film. 91 mins.

Soares, Benjamin, 2004, 'An African Muslim Saint and his followers in France', Journal of Ethnic and Migration Studies 30 (5): 913-927.

Stoller, Paul, 1999, Jaguar. A story of Africans in America, Chicago \& London: University of Chicago Press.

van den Looy, Judith, 2006, Africa and China: a strategic partnership? African Studies Centre Leiden, Working Paper 67.

van Dijk, Rijk, 2002, 'Religion, reciprocity and restructuring family responsibility in the Ghanaian Pentecostal movement', in Deborah Bryceson and Ulla Vuorela, eds., The transnational family: Global European networks and new frontiers. Oxford: Berg. pp. 173196.

van Velsen, J., 1961, Labour Migration as a Positive Factor in the Continuity of Tonga Tribal Society, in A. Southall, ed., Social Change in Modern Africa, London: Oxford University Press.

Vertovec, Steven, 1999, 'Conceiving transnationalism', Ethnic and Racial Studies 22 (2): 447462.

Warnier, Jean-Pierre, 1985, Échanges, développement et hierarchies dans le Bamenda précolonial (Cameroun). Stuttgart: Franz Steiner.

Whitwell, Chris, 2002, 'New migration' in the 1990s: a retrospective, Sussex: Working Papers of the Sussex Centre for Migration Research, No. 13. 